\title{
Influence of Emotional Intelligence on Teacher Effectiveness of Science Teachers
}

\author{
Della Gracia Soanes' ${ }^{1}$, S. M. Sungoh ${ }^{2}$ \\ ${ }^{1}$ Directorate of Educational Research and Training, Shillong, India \\ ${ }^{2}$ Department of Education, North Eastern Hill University, Shillong, India \\ Email: dellasoanes@gmail.com, smsungoh@yahoo.com
}

How to cite this paper: Soanes, D. G., \& Sungoh, S. M. (2019). Influence of Emotional Intelligence on Teacher Effectiveness of Science Teachers. Psychology, 10, 18191831.

https://doi.org/10.4236/psych.2019.1013118

Received: September 28, 2019

Accepted: October 22, 2019

Published: October 25, 2019

Copyright $\odot 2019$ by author(s) and Scientific Research Publishing Inc. This work is licensed under the Creative Commons Attribution International License (CC BY 4.0).

http://creativecommons.org/licenses/by/4.0/

\begin{abstract}
The present study is an attempt to explore the influence of Emotional Intelligence (E.I.) on Teacher Effectiveness (T.E.) of science teachers of secondary schools of East Khasi Hills District in Meghalaya $(\mathrm{N}=352)$. Emotional Intelligence inventory and Teacher Effectiveness scale were used to collect the data. Mean, Standard Deviation, $t$-test, and correlation were used for data analysis. The findings of the study revealed that there is a significant difference in Emotional Intelligence between male and female science teachers and female science teachers are slightly higher in Emotional Intelligence than their male counterparts. Further, there is no significant difference in Emotional Intelligence among the science teachers with respect to locale, community, qualification and teaching experience. There is no significant difference in Teacher Effectiveness among the science teachers with respect to gender, locale, community, qualification and teaching experience. The findings of the study revealed a relationship between Emotional Intelligence and Teacher effectiveness and between TE and the dimensions of EI. Although the correlation is neglible, EI influences TE to some extent.
\end{abstract}

\section{Keywords}

Emotional Intelligence, Teacher Effectiveness, Teacher Education, Science

Teacher

\section{Introduction}

Teaching is a demanding activity with vast operating locale. It depends on clearly defined set of competencies, skills, attributes possessed by experts working in this field. Teachers have greater responsibilities in overall development of physical, mental, emotional and intellectual growth of learners. They are required to take care of the affective domain of the students besides ensuring academic excel- 
lence. With technology taking the center stage these days, the teacher can no longer linger on the pathway of traditional style of teaching. Their competencies and effectiveness also depend on their innovation, vast usage of technology and managing of emotions which bring forth a great impact on the teaching learning process. The high feature continuous professional development of serving teachers should encapsulate those areas by updating their knowledge and equipping teachers with befitting competencies and skills. This would also reveal if the educational system is advancing or not. An emotionally intelligent teacher is one who imbibes emotional skills and practises the behaviour on a daily basis and experiences a more successful and contented professional career and life. Such a teacher knows when to be more resilient and proactive for different stressors and is not pressurised by stress.

Teachers who display emotional intelligence are described by deliberate reflective (not reactive) character, more flexible (not resilient to change), affirmative communication (not aggressive or passive), more future oriented and optimistic (not pessimistic and negative), and are creative and practice positive behaviours (nonreactive habits). To thrive towards academic excellence of students, teachers must possess strong Emotional Intelligence and effective teaching.

Intelligence is the most sought after personality qualities in today's society. I.Q. tests are presently dominating in selection procedures, diagnosis and evaluation. It is looked at as the single most actual predictor of individual performance at school and on the job. However, intelligence and success are now viewed as different indicators. New theories of intelligence have changed the outlook and are gradually swapping the customary theory. The success indicators are not anymore oriented on his/her reasoning capacities only, but also on his/her creativity, emotions, interpersonal skills and other related skills.

\section{Review of Literature}

Based on the literature review it was found that, Neelakandan $(2007)^{1}$ studied the Emotional Competence of Primary School Teachers and revealed that school teachers differed in emotional competence on the basis of qualification, type of school and service. The sample consisted of 300 primary school teachers of Cuddalore district in Tamil Nadu selected randomly. Emotional Competence Scale by Sharma and Bhardwaj was used which identified five different competencies in emotions such as in the adequate depth of feeling, expression and the control of emotions, the ability to function with emotions, to cope with problem in emotions and encouragement towards positive emotions. It was discovered that primary teachers showed average level of emotional competence. The teachers with higher qualifications were found to show better emotional competence than those having essential qualifications only. Hence the result showed that there is no significant difference between any two categories of sub-samples

${ }^{1}$ Neelakandan (2007) Emotional Competence of Primary School Teachers. EDUTRACKS, 6(9), 31-33. 
of teachers belonging to different groups in relation to their emotional competence. Further, the study revealed that there is no significant difference among teachers of government schools and private schools with respect to their level of emotional competence. Vishalakshi $(2013)^{2}$ in an analysis revealed that the Secondary School teachers do not differ in their level of Teacher Effectiveness and that a significant difference between Male and Female Secondary School Teachers in their total Emotional Intelligence and in two dimensions of EI viz., Self Awareness and Motivation existed. The male teachers had slightly higher EI than the female. Teachers of different age group and teaching experience differ in Emotional Intelligence, whereas Teachers of different qualifications did not differ in Emotional Intelligence. There is significant positive relationship between TE and EI.

Wangoo (1984) in a study on teacher personality correlates and scholastic competence as related to teacher effectiveness found that personality adjustment, democratic leadership, a high degree of intelligence, and emotional control were the main factors that influence Teacher Effectiveness. Sekreter (2019) in a study on Emotional Intelligence as a Vital Indicator of Teacher Effectiveness examined emotional intelligence (EI) with important work-related outcomes such as teacher performance as well as organizational productivity. The effect (role) of Emotional Intelligence skills in effective teaching, and its impact on the productivity of teacher's performance during the teaching-learning process were explored and found that effective teaching and good learning were two integral parts of students' academic success. It was also observed that emotional intelligence (EI) had set most effective teachers apart from the majority because process of learning involved emotional and intellectual endeavour, struggle, frustration, excitement and also anxiety. Therefore an affective teacher needed an understanding of students' emotional state and causes of their behavior to create an ideal learning environment that could encourage positive social interaction, active engagement and strong motivation to learn. In the light of exploration of the role of Emotional Intelligence in effective teaching-learning process, the study asserted that teachers' emotional competence factors contribute to the teacher effectiveness more than any other single factor.

Thus, the review shows that

- Age, and qualification influence the emotional intelligence of teachers whereas the type of school and service do not have any impact on their emotional intelligence

- In some studies, there is no significant difference between gender, subject, community, influence of others, previous teaching experience, study skill and the Emotional Intelligence of the student-teachers.

- Extroversion, introversion and feeling dimensions of personality have a negative impact on emotional intelligence of teachers, whereas thinking and judging dimensions have a positive impact on their emotional intelligence,

${ }^{2}$ Vishalakshi (2013) Teacher Effectiveness, Emotional Intelligence and Self-esteem of Secondary School Teachers. Ph.D. Mysore, India: University of Mysore. 
pulse control and problem solving skills.

- Emotional intelligence influences transformational leadership style.

- There is no relationship between Emotional Intelligence and General Intelligence and also between Academic Achievement whereas a relationship is established between Emotional Intelligence and Attitude towards Teaching Profession of Student Teachers.

- Emotional Intelligence can be learned and gradually enhanced.

\section{History of Development of EI}

In 1995, Daniel Goleman, a former editor of Psychology Today and at that time working for the New York Times, published Emotional Intelligence: Why It Can Matter More than IQ (Goleman 1995). In his book he declared that people's life success would be a lot of obsessed on their emotional quotient (EQ) than on their Intelligent Quotient (IQ). Yet in the same year, the American Dialect Society declared EQ to be the "most useful word of the year." Although the term EI had been generally unknown before the publication of Goleman's bestseller, it is not Goleman but doctoral student Wayne Payne who is said to have coined it: in 1986, Payne completed his unpublished thesis entitled "A Study of Emotion: Developing Emotional Intelligence.” It took another four years, in 1990, that Peter Salovey and John Mayer published their first paper on EI in a scientific psychological journal. The paper received little recognition from the scientific community, however, until Goleman's bestseller in 1995. Since then, the number of publications about EI has increased to thousands. Besides, Mayer and Salovey's idea of EI has become significant in the field of psychology.

Mayer and Salovey (1990) define EI as "a subset of social intelligence that involves the ability to monitor one's own and others' emotions, to discriminate among them, and to use this info to guide one's own thinking and actions" (Salovey and Mayer 1990, p. 189) ${ }^{3}$. Byron Stock (2007) defined it as, "the ability to acquire and apply knowledge from your emotions and the emotions of others." Bradberry and Greaves (2009) $)^{4}$ defined Emotional intelligence as the "ability to acknowledge and perceive emotions in yourself et al., and your ability to use this awareness to manage your behaviour and relationships". In the light of these, the impact of EI on TE may be noteworthy in the teaching profession.

Teachers' purpose is to provide an environment where course occurs easily and the students are totally engaged in learning. Well-qualified, caring and committed teachers will improve curricular and assessments and transform schools to the highest standards. Hence, teaching plays a vital role in developing Emotional Intelligence among students. It requires the teachers to interact with students, parents, colleagues, principals and non-teaching staff. The emotional competence of a person determines how much of his/her potential is tapped for the loads of capabilities in a teaching profession. Quality Science teaching may ${ }^{3}$ Salovey, P and Mayer, J.D. (1990) "Emotional Intelligence." Imagination, Cognition, and Personality9 (1990): 185-211. https://journals.sagepub.com/doi/10.2190/DUGG-P24E-52WK-6CDG. ${ }^{4}$ Emotional Intelligence, from http://www.talentsmart.com/about/emotional-intelligence.php. 
be defined as the ability of the teacher to captivate students during the lesson, to lend a hand and stimulate them intellectually and stir them emotionally to inculcate in them a passion for the subject and a craving to learn more about it, to prompt them to work on their own, to see them established in their wisdom and to experience the fulfillment of supporting them to grow into a great individual.

\section{Significance of the Study}

Due to significant roles and responsibilities, a teacher has to display; it becomes difficult for a teacher to have all competencies in perfect amalgam through professional development courses or experiences. A competent teacher is temperamentally convivial and amiable. He/she has unblemished visualization of the set objectives. He/she fulfils meticulously whatever that has been planned. All task done meritoriously by him/her inside and outside the classroom are impactful. His/Her skill of exhibition of the subject matter is able to gain attention of students, from all corners of the classroom even from the backbenchers ${ }^{5}$.

Numerous efforts were made to indigenize the system of Teacher Education in order to match the desired objectives. One of the efforts is seen in the features of the National Curriculum Framework 2005 viz., to be sensitive to the social, professional and administrative contexts in which the teachers need to operate.

Also, the National Commission on Teachers (1983-85) stressed on the measures to be given to the teacher; the status he/she needs so as to enable him/her do his/her duties at the highest possible level of performance, so that talented personnel are recruited for the job. It also emphasized on evolution of a system of teacher preparation for development of his/her skills and values to make his/her teaching and efforts of character building effective. Lastly, in order to help the teacher give the best in his/her duties the broad parameters should be indicated. In 2002, UNESCO started an international campaign to promote and support emotional learning in the classroom. The U.N. body sent a statement of 10 basic EQ principles that were drew heavily from Goleman's exposition of emotional intelligence to education ministries throughout the world ${ }^{6}$. Moreover, reports from teacher-effectiveness studies specified that teacher effectiveness has yielded a wealth of appreciation about the impact that teacher ability has on students' success. However, much is yet to be known on some psychological factors that could influence teaching effectiveness particularly among Science Teachers. Hence, the investigator chose the topic "Influence of Emotional Intelligence on Teacher Effectiveness of Science Teachers".

\section{Objectives of the Study}

The following are the objectives formulated for the Study:

${ }^{5}$ Bhargava \& Pathy (2011). Perception of Student Teachers about Teaching Competencies. American International Journal of Contemporary Research, 1 (1), 77-81.

${ }^{6}$ Concorda University (2013). Daniel Goleman's Emotional Intelligence Theory Explained. Concorda University, Portland. Retrieved, September 12, 2019, from

https://education.cu-portland.edu/blog/classroom-resources/daniel-golemans-emotional-intelligenc e-theory-explained/ 
1) To measure the level of Emotional Intelligence (EI) and to find out the level of Teacher Effectiveness (TE) of Science teachers of East Khasi Hills District.

2) To find out the significance differences in Emotional Intelligence among the Science teachers on the basis of their gender, community, locality, educational qualifications and teaching experience.

3) To determine the significant difference in Teacher Effectiveness among the Science teachers on the basis of their gender, community, locality, educational qualifications and teaching experience.

4) To measure whether there is a relationship between Emotional Intelligence and Teacher Effectiveness of Science teachers.

5) To find out any significant relationship between Teacher Effectiveness and the dimensions of Emotional intelligence of Science teachers.

\section{Null Hypotheses}

The hypotheses are as follows:

1) There is no significant difference between the mean scores of Emotional Intelligence of science teachers on the basis of gender, community, locality, educational qualifications and teaching experience.

2) There is no significant difference between the mean scores of Teacher Effectiveness of science teachers on the basis of gender, community, locality, educational qualifications and teaching experience.

3) There is no significant relationship between Emotional Intelligence and Teacher Effectiveness of science teachers.

4) There is no significant relationship between Teacher Effectiveness and dimensions of Emotional Intelligence of Science teachers.

\section{Methodology}

The method that was employed in the present study is the Descriptive survey.

\subsection{Details of the Population}

In the the present study, the population comprised of all the science teachers of Secondary Schools in East Khasi Hills District of Meghalaya. i.e., 544 science teachers of East Khasi Hills.

\subsection{Sample}

208 female and 144 male teachers were selected using Stratified random sampling.

Table 1 reflected the fact that the investigator has selected 352 Science teachers of Secondary Schools of East Khasi Hills District of Meghalaya as the sample of the study. Of these, 144 are males and 208 are females.

Hence, the sample of the study consisted of 352 Science Teachers of Secondary Schools of East Khasi Hills District of Meghalaya. 
Table 1. Showing the number of Science Teachers of Secondary Schools of East Khasi Hills District selected.

\begin{tabular}{ccccccc}
\hline \multirow{2}{*}{ Number of Science Teachers } \\
Types of Management & Locality & Tribal & \multicolumn{3}{c}{ Non Tribal } & Total \\
\cline { 3 - 7 } & & Male & Female & Male & Female & \\
\hline \multirow{2}{*}{ Government } & Urban & - & 4 & - & - & 4 \\
& Rural & 4 & 3 & 1 & - & 8 \\
Aided & Urban & 7 & 22 & 16 & 15 & 60 \\
& Rural & 43 & 54 & 19 & 4 & 120 \\
Private & Urban & 5 & 18 & 8 & 12 & 43 \\
& Rural & 34 & 70 & 7 & 6 & 117 \\
Total & & 93 & 171 & 51 & 37 & 352 \\
\hline
\end{tabular}

Source: District School Education Office (2019) ${ }^{7}$.

\subsection{Tools}

The following standardized tools were employed for data collection.

1) Teachers Emotional Intelligence Inventory (2008), tEQi, developed by Dr. (Mrs.) Shubhra Mangal (2008).

2) Teacher Effectiveness Scale (2011), TES-KU, developed by Umme Kulsum (2011).

\section{Analysis and Interpretation of Data}

In this present study, the data collected using the selected tools were entered in a tabular form, in a classified manner and then analyzed by the descriptive and inferential statistics such as Mean, Standard Deviation, t-test, and coefficient of correlation.

\subsection{Levels of Emotional Intelligence and Teacher Effectiveness}

\section{Interpretation:}

1) Table 2 revealed that $71.02 \%$ of the science teachers were placed under the average level with respect to Emotional Intelligence (EI) and with regards to Teacher Effectiveness (TE), 82.64\% showed a high level of TE.

2) Analysis of the responses as per the mean scores showed that the level of Emotional Intelligence (790.96) is average and the level of Teacher Effectiveness (478.41) is high. As seen from Table 3 \& Table 4, the mean scores of Emotional Intelligence and Teacher Effectiveness of science teachers it can be implied that:

a) Most of the Science teachers are placed in the average level of Emotional Intelligence.

b) Majority of the Science teachers are in the high level of Teacher Effectiveness.

${ }^{7}$ District School Education Office (2019) Unpublished Report. Shillong, India: DSEO. 
Table 2. Showing the levels of emotional intelligence and teacher effectiveness, frequency and percentage of science teachers of secondary schools.

\begin{tabular}{ccc}
\hline \multirow{2}{*}{ Level } & Emotional Intelligence & Teacher Effectiveness \\
\cline { 2 - 3 } & $\mathbf{N}(\%)$ & $\mathbf{N}(\%)$ \\
\hline High & $60(17.05)$ & $312(88.64)$ \\
Average & $250(71.02)$ & $31(8.81)$ \\
Poor & $42(11.93)$ & $9(2.55)$ \\
\hline
\end{tabular}

Table 3. Showing the mean and SD of Emotional Intelligence (EI) and Teacher Effectiveness (TE) of Science Teachers.

\begin{tabular}{cccccc}
\hline Variables & Number & Minimum & Maximum & Mean & SD \\
\hline EI & 352 & 375 & 968 & 790.96 & 90.13 \\
TE & 352 & 84 & 599 & 478.41 & 72.74 \\
\hline
\end{tabular}

Table 4. Showing the level of Emotional Intelligence (EI) and Teacher Effectiveness (TE) of Science Teachers in terms of mean scores.

\begin{tabular}{ccc}
\hline Levels & Teacher Effectiveness & Emotional Intelligence \\
\hline High & 551.15 & 881.09 \\
Average & 478.41 & 790.96 \\
Low & 405.67 & 700.83 \\
\hline
\end{tabular}

\subsection{Testing of Hypotheses}

Hypothesis 1: There is no significant difference between the mean scores of the Emotional Intelligence of science teachers on the basis of gender, community, locality, educational qualifications and teaching experience.

As Table 5 showed that there was a significant difference in Emotional Intelligence between male and female Science Teachers of Secondary Schools in East Khasi Hills District at .05 level (Garrett, 2012), (" $\mathrm{t} "=2.36$ ); the null hypothesis is rejected. It was also observed that the mean scores of female science teachers were slightly higher than the mean scores of male science teachers. This shows that the female science teachers were slightly higher in EI than their male counterparts.

Hypothesis 2: There is no significant difference between the mean scores of the Teacher Effectiveness of science teachers on the basis of gender, community, locality, educational qualifications and teaching experience.

It was also observed from Table 6 that there is no significant difference between the mean scores of the Teacher Effectiveness of science teachers on the basis of gender, community, locality, educational qualifications and teaching experience. Hence the null hypotheses is retained. Thus gender, community, locality, educational qualifications and teaching experience do not have any effect on Teacher Effectiveness.

Hypothesis 3: There is a positive relationship between Emotional intelligence and Teacher Effectiveness of science teachers.

Table 7 showed that there is a positive relationship (" $\mathrm{r}$ " $=.186$ ) between Emo- 
tional Intelligence and Teacher Effectiveness of Science teachers of Secondary schools in East Khasi Hills District at .01 level. Although the Correlation is negligible. Hence, the null hypothesis is rejected. Thus it can be concluded that there is a positive relationship between Emotional Intelligence and Teacher Effectiveness of Science teachers.

Hypothesis 4: There is no significant relationship between Teacher Effectiveness and dimensions of Emotional Intelligence

Table 8 showed that there is positive relationship (" $\mathrm{r}$ " $=.187, .135, .088, .155$ ) between Teacher Effectiveness and dimensions of Emotional Intelligence of Science teachers of Secondary schools in East Khasi Hills District. Although the Correlation is negligible. Hence, the null hypothesis is rejected. Thus, it can be concluded that there is a positive relationship between Teacher Effectiveness and the dimensions of Emotional Intelligence of Science teachers. Hence, it implies that the dimensions of Emotional Intelligence of Science teachers influence their Teacher Effectiveness to some extent.

Table 5. Showing the difference between the mean scores of Emotional Intelligence and the Sub-variables.

\begin{tabular}{|c|c|c|c|c|c|c|}
\hline Variables & Sub variables & Number & Mean & Sd & df & t-value \\
\hline \multirow{2}{*}{ Gender } & Male & 144 & 777.44 & 94.54 & \multirow[t]{2}{*}{350} & \multirow[t]{2}{*}{$2.36^{\star}$} \\
\hline & Female & 208 & 800.32 & 85.94 & & \\
\hline \multirow{2}{*}{ Community } & Tribal & 264 & 789.73 & 87.63 & \multirow{2}{*}{350} & \multirow{2}{*}{.44} \\
\hline & Non Tribal & 88 & 794.66 & 97.68 & & \\
\hline \multirow{2}{*}{ Locality } & Urban & 106 & 799.01 & 96.19 & \multirow{2}{*}{350} & \multirow{2}{*}{11.51} \\
\hline & Rural & 246 & 787.50 & 87.37 & & \\
\hline \multirow{2}{*}{ Qualification } & Graduates & 206 & 792.85 & 85.15 & \multirow{2}{*}{350} & \multirow{2}{*}{.47} \\
\hline & Post Graduates & 146 & 788.30 & 96.96 & & \\
\hline \multirow{2}{*}{$\begin{array}{c}\text { Teaching } \\
\text { Experience }\end{array}$} & Junior (<10 Years) & 229 & 788.87 & 87.28 & \multirow{2}{*}{350} & \multirow{2}{*}{.593} \\
\hline & Senior $(>10$ Years $)$ & 123 & 794.85 & 95.46 & & \\
\hline
\end{tabular}

Table t-value $=1.97,{ }^{*}$ significant at .05 level.

Table 6. Showing the difference between the mean scores of Teacher Effectiveness and the Sub-variables.

\begin{tabular}{|c|c|c|c|c|c|c|}
\hline Variables & Sub variables & Number & Mean & Sd & df & t-value \\
\hline \multirow{2}{*}{ Gender } & Male & 144 & 474.94 & 71.35 & \multirow[t]{2}{*}{350} & \multirow[t]{2}{*}{.745} \\
\hline & Female & 208 & 480.82 & 73.76 & & \\
\hline \multirow{2}{*}{ Community } & Tribal & 264 & 477.89 & 73.90 & \multirow{2}{*}{350} & \multirow{2}{*}{.231} \\
\hline & Non Tribal & 88 & 479.97 & 69.52 & & \\
\hline \multirow{2}{*}{ Locality } & Urban & 106 & 487.38 & 62.41 & \multirow{2}{*}{350} & \multirow{2}{*}{1.52} \\
\hline & Rural & 246 & 474.55 & 76.56 & & \\
\hline \multirow{2}{*}{ Qualification } & Graduates & 206 & 477.02 & 78.27 & \multirow{2}{*}{350} & \multirow{2}{*}{.425} \\
\hline & Post Graduates & 146 & 480.37 & 64.35 & & \\
\hline \multirow{2}{*}{$\begin{array}{c}\text { Teaching } \\
\text { Experience }\end{array}$} & Junior (<10 Years) & 229 & 478.15 & 74.76 & \multirow{2}{*}{350} & \multirow{2}{*}{.091} \\
\hline & Senior ( $>10$ Years) & 123 & 478.90 & 68.12 & & \\
\hline
\end{tabular}

Table t-value $=1.97,{ }^{*}$ significant at .05 level. 
Table 7. Relationship between Emotional Intelligence and Teacher Effectiveness of Science teachers $(\mathrm{N}=352)$.

\begin{tabular}{ccc}
\hline Correlation between & Emotional Intelligence & Teacher Effectiveness \\
\hline Emotional Intelligence & 1 & $.186^{* *}$ \\
Teacher Effectiveness & $.186^{* *}$ & 1 \\
\hline
\end{tabular}

**. Correlation is significant at the .01 level (2-tailed).

Table 8. Relationship between Teacher Effectiveness and dimensions of Emotional Intelligence of Science teachers $(\mathrm{N}=352)$.

\begin{tabular}{cccccc}
\hline & $\begin{array}{c}\text { Teacher } \\
\text { Effectiveness }\end{array}$ & $\begin{array}{c}\text { Awareness of } \\
\text { self \&others }\end{array}$ & $\begin{array}{c}\text { Professional } \\
\text { Orientation }\end{array}$ & $\begin{array}{c}\text { Intrapersonal } \\
\text { ManagementI }\end{array}$ & $\begin{array}{c}\text { Interpersonal } \\
\text { Management }\end{array}$ \\
\hline $\begin{array}{c}\text { Teacher } \\
\text { Effectiveness }\end{array}$ & 1 & $.187^{* *}$ & $.135^{*}$ & .088 & $.155^{* *}$ \\
$\begin{array}{c}\text { Awareness of } \\
\text { self \& others }\end{array}$ & $.187^{* *}$ & 1 & $.613^{* *}$ & $.430^{* *}$ & $.590^{* *}$ \\
$\begin{array}{c}\text { Professional } \\
\text { Orientation }\end{array}$ & $.135^{*}$ & $.613^{* *}$ & 1 & $.539^{* *}$ & $.684^{* *}$ \\
$\begin{array}{c}\text { Intrapersonal } \\
\text { management }\end{array}$ & .088 & $.430^{* *}$ & $.539^{* *}$ & 1 & $.545^{* *}$ \\
$\begin{array}{c}\text { Interpersonal } \\
\text { Management }\end{array}$ & $.155^{* *}$ & $.590^{* *}$ & $.684^{* *}$ & $.545^{* *}$ & 1 \\
\hline
\end{tabular}

${ }^{* *}$. Correlation is significant at the .01 level (2-tailed). ${ }^{*}$. Correlation is significant at the .05 level (2-tailed).

\section{Major Findings}

- The present study reveals that the science teachers have average level of Emotional Intelligence and their TE is observed to be high.

- The Emotional Intelligence influences the Teacher Effectiveness. The dimensions of Emotional Intelligence also influence Teacher Effectiveness of Science teachers to some extent.

- There is significant difference in Emotional Intelligence among the male and female science teachers. Female teachers are slightly higher in EI compared to their male counterparts.

- There is no significant difference in the Emotional Intelligence in terms of community, locale, Educational Qualifications and Teaching Experience of Science Teachers.

- There is no significant difference in the Teacher Effectiveness in terms of gender community, locale, Educational Qualifications and Teaching Experience of Science Teachers.

- There is positive relationship between Emotional Intelligence and Teacher Effectiveness of Science teachers.

- There is positive relationship between Teacher Effectiveness and dimensions of Emotional Intelligence of Science teachers.

\section{Educational Implications}

The findings revealed that most Science Teachers of Secondary Schools had av- 
erage level of Emotional Intelligence. The finding is also similar to that of Suvarna (2015) who concluded that Science Teachers had an average level of Emotional Intelligence. Most of the Science Teachers of Secondary Schools need to be given training on EI. There should be enhancement in their professional orientation, intrapersonal management as well as an average interpersonal management, which are the factors contributing for the development of high Emotional Intelligence as they may be lacking in these areas.

It was also inferred that Female teachers are slightly higher in EI compared to their male counterparts. This finding is also supported by a study conducted by Amirtha \& Kadhiravan (2006) who found that Female teachers had better impulse control and problem solving skills. The same was observed by Sjoberg (2008), in which women got highest score than men in EI. However, the findings is just the reverse of Adhikari (2011) who found out that Emotional Intelligence (EI) of Male Secondary Teachers is higher than that of female. Syiem (2009) also observed that male were found to have higher EI compared to female. Another finding of Mandell \& Pherwani (2003) revealed that no significant interaction was found between gender and emotional intelligence.

Also, the study showed that there is significant relationship between Emotional Intelligence and Teacher Effectiveness of Science teachers at .01 level. This is in agreement with the findings of Suvarna (2015) who revealed that there is a moderate positive relationship between Emotional Intelligence and Teacher Effectiveness of Secondary Schools. Padhi \& Verma (2011) and Vishalakshi (2013) also found that there is significant correlation between Teacher Effectiveness and Emotional Intelligence. Wangoo (1984) in a study also found that a high degree of intelligence and emotional control were the main characteristics that influence teacher effectiveness.

Emotional intelligence skills can be acquired by anyone at anytime. Anticipatory, anxious, fatalistic and affirming emotions are a few conditions required to indicate emotions. Emotional environments influences on the teacher's ability to be able to perform efficiently. A sea of rapid changes that may take place and increase in responsibilities leading to pressures in all aspects, may pose challenges on teachers in coping with. So teachers are required to develop active coping skills.

\section{Suggestions}

1) Findings indicated that the teachers should be given more awareness and orientation on emotional intelligence to make them aware of the different dimensions of Emotional Intelligence. A better educational outcome can only then be achieved if the teachers are high in both EI and TE. Innovative Teacher Education programmes should be encouraged to motivate the teachers to be up-to-date and innovative thereby enabling them to be more emotionally intelligent and effective. Training programmes should also be research-based to yield positive results in education. The impact of training programmes should ensure better effective teachers. Reports of training programmes conducted should form 
a basis for further improvement of education.

2) Lastly, it is important to note that, there are very concrete reasons to promote social and emotional learning in schools at all levels. According to Goleman, the various problems like bullying, disciplinary problems, violence and drug abuse can be addressed in schools with application of emotional Intelligence. The EQ of children starts developing long before they ever joined school. EQ levels vary widely, depending on the learners' home environment. With a solid basis in emotional intelligence, academic performance as well as a sound behaviour, learners can be controlled and improved. Thus teachers' emotional intelligence to recognize children with much needed emotional literacy will boost their teaching. Teachers should be ready to talk about feelings in the classroom. The message is that no emotion is "wrong," but certain ways of expressing those emotions or acting on them are indeed inappropriate.

\section{Conclusion}

Sekreter (2019) in a study on Emotional Intelligence as a Vital Indicator of Teacher Effectiveness was right when it was concluded that emotional intelligence (EI), is the most important factor. EI have set most effective teachers apart from the majority because process of learning involved emotional and intellectual endeavour, struggle, frustration, excitement and anxiety. Therefore, an effective teacher needed an understanding of students' emotional state and causes of their behaviour to create an ideal learning environment that could encourage positive social interaction, active engagement and strong motivation to learn. They should be able to design specific kinds of help in finding solutions for day to day problems related to educational, personal and social situations.

Thus in the light of researches of the role of Emotional Intelligence in effective teaching-learning, it can be inferred that teachers' emotional Intelligence factors contribute to the teacher effectiveness more than any other factor. A teacher can be more effective in teaching if they have high emotional intelligence. They can plan the lessons as per the desired goals and can manage the classroom well keeping in mind the individual differences of the learners.

There can be few limitations of any research, hence, it is suggested that the current research study may be extended to a larger sample covering the whole state of Meghalaya so as to determine the level of Emotional Intelligence and Teacher Effectiveness of Science teachers of Secondary schools of the state. Since Emotional Intelligence can be learnt, a study to ascertain the factors of Emotional Intelligence that need to be developed for teachers, teacher educators and educational administrators may be conducted and awareness should be made in order to assess and improve upon Emotional Intelligence.

\section{Conflicts of Interest}

The authors declare no conflicts of interest regarding the publication of this paper. 


\section{References}

Adhikari, S. R. (2011). Emotional Intelligence among Secondary School Teachers of Sikkim in Relation to Their Teaching Aptitude. PhD Thesis, Shillong: North Eastern Hill University.

Agarwall, J. C., \& Gupta, S. (2010). Elementary Educational Technology (p. 44). Shakarpur: Shipra Publications.

Amirtha, M., \& Kadhiravan, S. (2006). Influence of Personality on the Emotional Intelligence of Teachers. Edutracks, 5, 25-29.

Bhargava, A., \& Pathy, M. (2011). Perception of Student Teachers about Teaching Competencies. American International Journal of Contemporary Research, 1, 77-81.

Concorda University (2013). Daniel Goleman's Emotional Intelligence Theory Explained. Montréal: Concordia University.

https://education.cu-portland.edu/blog/classroom-resources/daniel-golemans-emotion al-intelligence-theory-explained

Emotional Intelligence. http://www.talentsmart.com/about/emotional-intelligence.php

Garrett, H. E. (2012). Statistics in Psychology and Education. Kamla Nagar: Surjeet Publications.

Kulsum, U. (2011). Manual for Teacher Effectiveness Scale. Agra: National Psychological Corporation.

Mandell, B., \& Pherwani, S. (2003). Relationship between Emotional Intelligence and Transformational Leadership Style: A Gender Comparison. Journal of Business and Psychology, 17, 387-404. http://www.jstor.org/stable/25092828 https://doi.org/10.1023/A:1022816409059

Mangal, S. (2008). Manual for Teachers' Emotional Intelligence Inventory. Agra: National Psychological Corporation.

Neelakandan, R. (2007). Emotional Competence of Primary School Teachers. Edutracks, 6, 31-33.

Padhi, S. K., \& Verma, J. (2011). Effectiveness of Secondary School Teachers in Relation to Emotional Intelligence and Life Satisfaction. Edutracks, 11, 20-25.

Sekreter, G. (2019). Emotional Intelligence as a Vital Indicator of Teacher Effectiveness. International Journal of Social Sciences \& Educational Studies, 5, 286-302.

http://ijsses.org/wp-content/uploads/2019/04/Emotional-Intelligence-as-A-Vital-Indic ator-of-Teacher-Effectiveness.pdf https://doi.org/10.23918/ijsses.v5i3p286

Sjoberg, L. (2008). Emotional Intelligence and Life Adjustment. Counterpoints, 336, 169-183. http://www.jstor.org/stable/42980148

Suvarna, V. D. (2015). Teacher Effectiveness in Relation to Emotional Intelligence and Personality Type of Secondary School Science Teachers.

https://shodhganga.inflibnet.ac.in/handle/10603/9401

Syiem, I. (2009). Emotional Intelligence and Its Relationship to Selected Personality Characteristics of Secondary School Students of Meghalaya. PhD Thesis, Shillong: North Eastern Hill University.

Vishalakshi, K. K. (2013). Teacher Effectiveness, Emotional Intelligence and Self-Esteem of Secondary School Teachers. PhD, Mysuru: University of Mysore.

Wangoo, M. L. (1984). Teacher Personality Correlates and Scholastic Competence as Related to Teacher Effectiveness. In M. B. Buch (Ed.), Fourth Survey of Educational Research, 1983-1988 (Volume II, p. 1005). New Delhi: NCERT. 